\title{
AKRUAL
}

Jurnal Akuntansi

http://journal.unesa.ac.id/index.php/aj

\section{PENERAPAN SISTEM E-BUDGETING TERHADAP TRANSPARANSI DAN AKUNTABILITAS KEUANGAN PUBLIK (STUDI PADA PEMERINTAH KOTA SURABAYA)}

\author{
Dimas Rizky Gunawan \\ Jurusan S-1 Akuntansi, Fakultas Ekonomi, Universitas Negeri Surabaya \\ dimasrizkygunawan@yahoo.com
}

\begin{abstract}
Surabaya adalah salah satu kota yang menggunakan teknologi informasi dalam akuntabilitas dan transparansi anggaran melalui pelaksanaan e-budgeting. Surabaya juga salah satu kota yang memiliki transparansi anggaran yang baik dan dilakukan secara online dengan menggunakan kemajuan teknologi informasi. Penerapan akuntabilitas dan transparansi anggaran pemerintah di kota Surabaya telah terwujud. Realisasi akuntabilitas bisa dilihat dari upaya pemerintah mempublikasikan pelaksanaan proses penganggaran dan program kegiatan Pemerintah Kota secara menyeluruh. Perwujudan transparansi informasi anggaran dalam penelitian ini dapat dilihat melalui informasi anggaran yang diberikan oleh Pemerintah Kota Surabaya. Implementasi berjalan dengan baik dan sesuai dengan prosedur operasional standar. Penelitian ini menggunakan penelitian deskriptif kualitatif. Lokasi yang dipilih dalam penelitian ini adalah pemerintah kota Surabaya.
\end{abstract}

Kata Kunci: Akuntabilitas, E-Budgeting, Pemerintah Kota Surabaya, Transparansi

\section{PENDAHULUAN}

\section{Latar Belakang}

Kemajuan teknologi pada telekomunikasi dan teknologi informasi pada akhirnya menjadikan perubahan terhadap tatanan organisasi dan hubungan sosial dan kemasyarakatan. Hal ini menimbulkan suatu perubahan dalam aktivitas kehidupan masyarakat dalam berbagai sektor. Salah satunya sektor publik yang terjadi di dalam organisasi pemerintah. Perkembangan teknologi informasi dan komunikasi dapat melahirkan model pelayanan publik yang dilakukan melalui electronic system (Soesetyo, 2013).

Penggunaan teknologi informasi dan komunikasi (Information and Communication Technology) dari tahun ke tahun selalu mengalami perkembangan. Bisa dilihat sehari-hari dari penggunaan Informasi dan komunikasi ini tidak terbatas pada bidang perdagangan atau bisnis, melainkan juga dalam bidang pertahanan negara, bidang pendidikan, pemerintah negara, bidang sosial, dan masih banyak lagi tentunya. Penggunaan teknologi informasi dan komunikasi ini dipergunakan karena memiliki kelebihan-kelebihan yang menguntungkan dibandingkan dengan menggunakan cara tradisional dalam melakukan interaksi. Hal ini juga berlaku dan mengharuskan organisasi secara terus menerus 
melakukan pengembangan peningkatan serta perubahan. Perubahan yang dilakukan organisasi yang paling penting yaitu untuk mencapai tujuan yang diinginkan oleh organisasi yakni peningkatan produktivitas, peningkatan pelayanan, peningkatan moral dan kapasitas anggota dan pelayanan publik yang dilakukan oleh pemerintah. Dengan berkembangnya teknologi informasi dan komunikasi telah menciptakan model pelayanan publik yang dilakukan melalui E-Government (Gallego-Álvarez, Rodríguez-Domínguez, \& García-Sánchez, 2010).

Menurut Emilsyah (2014) E-Government merupakan sistem informasi manajemen dalam bentuk implementasi pelayanan publik yang berbasis teknologi informasi dan komunikasi, yang digunakan sebagai media informasi dan komunikasi secara interakif antara pemerintah dengan kelompok-kelompok masyarakat dan sesama lembaga pemerintahan itu sendiri. E-Government yang dilakukan oleh pemerintah dimulai dari bentuk layanan yang sederhana yaitu penyediaan informasi dan data-data berbasis komputer tentang pelaksanaan pemerintahan dan pembangunan sebagai bentuk wujud transparansi dalam pelayanan publik. Dari sudut pemerintahan E-Government juga bisa dimanfaatkan sebagai sarana komunikasi baik intern di kalangan Satuan Kerja Perangkat Daerah (SKPD) maupun masyarakat. Dengan adanya E-Government, pemerintah juga memberikan inovasi terhadap suatu sistem keuangan yang bisa memberikan kemudahan kinerja organisasi pemerintah yaitu E-Budgeting.

Undang-Undang (UU) Republik Indonesia No 22 Tahun 1999 yang sekarang diganti dengan UU No.32 Tahun 2004 yang kemudian menjadi UU. Nomor 23 Tahun 2014 menandai tentang diimplementasikannya otonomi daerah. Misi utama dari pelaksanaan otonomi daerah ini adalah penyerahan sebagian besar kewenangan dari pemerintah pusat kepada pemerintah daerah. Konsekuensi penyerahan kewenangan ini di satu sisi daerah diberikan keleluasaan untuk mengurusrumah tangganya sendiri dengan potensi yang dimiliki, tetapi di sisi lain mengandung tanggung jawab yang besar asas keberhasilan suatu pelaksanaan otonomi daerah, karenaa menurut asas otonomi dan tugas pembantu diarahkan untuk mempercepat terwujudnya kesejahteraan masyarakat melalui peningkatan pelayanan, pemberdayaan dan peran masyarakat. Serta peningkatan daya saing daerah dengan memperhatikan prinsip demokrasi, pemerataan, keadilan, hukum yang berlaku, serta mengutamakan kesejahteraan masyarakat.

Akuntabilitas keuangan merupakan pertanggungjawaban mengenai integritas keuangan, pengungkapan, dan ketaatan terhadap peraturan perundang-undangan. Bentuk pertanggungjawaban ini adalah laporan keuangan dan peraturan perundang-undangan 
yang berlaku mencakup penerimaan, penyimpanan, dan pengeluaran uang oleh instansi pemerintah (LAN dan BPKP, 2000). Penilaian pemerintah telah bekerja dengan ekonomis, effisien, dan efektif atau belum bisa dilihat dari hasil dari laporan program yang telah dilaksanakan sehingga masyarakat bisa menilainya. Akuntabilitas juga dapat dilihat dari perspektif akuntansi, perspektif fungsional, dan perspektif sistem akuntabilitas (Rinaldi, 2016).

Mewujudkan sistem pemerintah yang baik (good governance) yang merupakan persyaratan bagi setiap pemerintah untuk memenuhi aspirasi masyarakat dan mencapai tujuan serta cita-cita bangsa dan negara. Good Governance merupakan suatu konsep pendekatan yang berorientasi kepada pembangunan sektor publik oleh pemerintah yang baik (Mardiasmo, 2002).

Beberapa penelitian menunjukan bahwa pentingnya instansi untuk menerapkan teknologi memiliki hasil yang bervariatif. (Garcia, 2004) menyebutkan bahwa keunggulan kompetitif dari teknologi memberikan pengaruh positif pada kinerja dari sektor swasta (perusahaan). Sedangkan dalam sektor publik sendiri, (Elizabeth Pinnington, 2009) menjelaskan bahwa penggunaan informasi teknologi memberikan pengaruh pada pencapaian positif yang diterima oleh instansi yang menerapkan pembelajaran berbasis teknologi. Dalam sektor pemerintah, penerapan teknologi seperti e-government juga memberikan dampak yang positif pada peningkatan kinerja instansi (Baker,2008). Tetapi tidak sepenuhnya penerapan teknologi akan berjalan dengan sukses, (Wu Jie, 2015) menyebutkan bahwa tidak semua provinsi di Cina mengalami efisiensi setelah menerapkan website e-government. Beberapa provinsi masih belum dapat menerapkan teknologi tersebut secara maksimal. Hal tersebut mengindikasikan hasil yang beragam dari adanya penerapan teknologi dalam pemerintahan.

Laporan keuangan yang akuntabel menuntut pemerintah menyusun serta menyajikan laporan keuangan publiknya sesuai pada Standar Akuntansi Pemerintah (SAP), dalam SAP No. 01 menyebutkan bahwa penyajian laporan keuangan pemerintah bertujuan untuk meningkatkan keterbandingan laporan keuangan serta untuk menyajikan informasi yang berkaitan dengan posisi keuangan, realisasi anggaran, arus kas dan kinerja keuangan dari pemerintah. Semua informasi tersebut digunakan oleh pihak yang terkait dengan pertanggungjawaban laporan keuangan pemerintah terhadap masyarakat sebagai sumber dana. Tujuan-tujuan itulah yang menyebabkan diperlukannya sebuah standar yang memuat pedoman struktur laporan keuangan, dan persyaratan minimum isi laporan keuangan pemerintah paling tidak adalah relevan, andal, dapat dibandingkan dan dapat 
dipahami. Hal tersebut disebabkan karena organisasi sektor publik merupakan organisasi yang menggunakan sumber dana publik sehingga harus memberikan pertanggungjawaban melalui laporan keuangan sebagai wujud akuntabilitas.

Anggaran memiliki peran penting dalam tata kelola pemerintah. Anggaran sebagai alat kebijakan, perencanaan, pengendalian dan penilaian kinerja memiliki peranan yang cukup strategis dalam upaya pemerintah mewujudkan kemakmuran masyarakat. Sistem penganggaran pada pemerintah Indonesia telah mengalami pergeseran dari sistem anggaran tradisional menjadi anggaran kinerja (Halim \& Kusufi, 2012). Pergeseran ini terjadi karena akuntabilitas dan transparansi yang kurang dalam pengelolaan anggaran. Sistem anggaran kinerja tidak hanya menekankan pada input anggaran seperti pada sistem anggaran tradisional, tetapi juga pada output dan outcome. Hal ini mengisyaratkan bahwa penganggaran kinerja memiliki tolok ukur dalam pencapaian tujuan dan sasaran pelayanan publik (Nordiawan, 2007).

E-Budgeting merupakan sistem informasi yang digunakan untuk penyusunan anggaran guna meningkatkan efisiensi dan efektivitas dalam proses penganggaran. Sistem E-Budgeting memberikan peranan yang penting dalam pembuatan anggaran. Sistem tersebut mampu mempersingkat waktu yang diperlukan dalam proses pembuatan anggaran karena dilakukan secara online dan dapat di akses dimana saja. Sistem ini juga berfungsi sebagai alat pengawasan kerja yang dapat memantau poses dalam penyusunan anggaran. Selain itu, prosedur dalam E-Budgeting juga dapat mengantisipasi potensi adanya mark-up dengan adanya sistem saling mengawasi (ebudgeting.surabaya.go.id diakses 15 Januari 2017).

Upaya yang dilakukan pemerintah untuk mewujudkan pertanggungjawaban keuangan yang baik dan benar adalah dengan menetapkan Standar Akuntansi Pemerintahan (SAP) sesuai dengan Peraturan Pemerintah No. 24 Tahun 2005. Namun, pada tahun 2010 disahkan peraturan baru mengenai SAP yaitu tentang sistem akuntansi pemerintah daerah yang berbasis akrual sesuai dengan Peraturan Pemerintah Nomor 71 tahun 2010. Perwujudan akuntabilitas dan transparansi laporan keuangan pemerintah daerah dapat dilakukan dengan menyajikan laoran keuangan sesuai dengan laporan keuangan pemerintah daerah dapat dilakukan dengan menyajikan laporan keuangan sesuai dengan standar yang telah ditetapkan serta dilaporkan tepat waktu dan dapat diandalkan. Adanya Standar Akuntansi Pemerintahan diharapkan setiap pemerintah daerah dapat menyusun laporan keuangan daerahnya dengan baik dan benar serta sesuai dengan peraturan yang telah ditetapkan agar tercipta pemerintahan yang baik. Tata kelola 
pemerintahan yang baik (good governance) memiliki hal terpenting yaitu transparansi, akuntabilitas dan partisipatif (Zeyn, 2011).

Provinsi Jawa Timur merupakan pelopor dalam penggunaan sistem E-Budgeting salah satu nya di kota Surabaya. Sistem ini pertama kali dirintis dari pemerintah kota Surabaya dan di adopsi oleh pemerintah DKI Jakarta pada tahun 2015 (Agus, 2016). Surabaya sebagai kota salah satu kota panutan dari kota maupun kabupaten yang berada di Jawa Timur terkait dalam penerapan E-Budgeting yang telah sukses diterapkan. Selain itu beragam penghargaan juga diterima oleh pemerintah Kota Surabaya terkait penerapan teknologi guna menunjang pelayanan birokrasi.

Surabaya dinilai mampu melakukan inovasi, efisiensi dan unggul dalam manajemen proyek di sekitar pusat data. Program yang sudah di kelola oleh ibu Tri Risma selaku walikota Surabaya merupakan fasilitas teknologi informasi yang dapat dinikmati masyarakat Surabaya secara gratis guna mendapatkan pelayanan dan data secara transparan, akuntabel dan memangkas birokrasi (kominfo.go.id).

Pada tahun 2013 Surabaya memperoleh penghargaan tingkat Asia-Pasifik yaitu Future Government Award 2013. Penghargaan lainnya yaitu sebagai Pelopor Pemanfaatan Teknologi Informasi dan Komunikasi dalam PPID (Pejabat Pengelola Informasi dan Komunikasi) Award (Surabaya.go.id). Berdasarkan praktik dan teori di atas maka perlu dilakukan penelitian yang berjudul "Penerapan E-Budgeting terhadap transparansi dan akuntabilitas keuangan publik pada Pemerintah Kota Surabaya".

\section{KAJIAN PUSTAKA}

\section{Teori Stewardship}

Stewardship Theory yang dikembangkan oleh Donaldson and Davis (1991) adalah paradigma baru untuk memahami adanya hubungan antara pemilik dan manajemen dari organisasi. Dalam pengelolaan StewardshipTheory organisasi difokuskan pada harmonisasi antara pemilik modal (principles) dengan pengelola modal (steward) dalam mencapai tujuan bersama.

Teori ini menggambarkan situasi dimana para manajer (manajemen) termotivasi pada tujuan dari hasil utama mereka untuk kepentingan organisasi dengan mengesampingkan tujuan-tujuan individu. Dalam teori ini manajemen sebagai steward termotivasi untuk bertindak sesuai keinginan principal. Selain itu, perilaku steward cenderung loyal pada organisasinya karena steward berusaha mencapai sasaran organisasinya. 
Dalam sektor pemerintah steward sebagai manajemen dapat diartikan Pemerintah Daerah dan principal diartikan sebagai rakyat. Teori ini beranggapan kepentingan rakyat dapat dimaksimalkan dengan membagi wewenang, hak dan kewajiban kepada manajemen/steward (Sari, 2010). Dengan demikian, steward (manajemen) yang diberi kepercayaan oleh principal (rakyat) akan semakin termotivasi untuk bertindak sesuai tujuan organisasi (pemerintah daerah) dibanding kepentingan sendiri. Penggunaan teori stewardship dalam penelitian ini yaitu pemerintah dalam mencapai tujuan visi dan misinya, salah satunya dapat menggunakan alat berupa E-Budgeting untuk meningkatkan effisiensi dan efektivitas penyusunan anggaran sehingga mampu untuk mendorong transparansi dan akuntabilitas publik.

Teori stewardship mengasumsi bahwa ada hubungan yang kuat antara kesuksesan organisasi dengan kepuasan principal. Steward melindungi dan memaksimalkan kepuasan principal melalui kinerja yang dicapai. Steward yang berhasil meningkatkan kinerja akan mampu memuaskan organisasi karena sebagian besar rakyat memiliki kepentingan yang telah dilayani dengan baik lewat peningkatan kemakmuran yang diraih organisasi. Oleh karena itu, steward yang pro organisasi termotivasi untuk memaksimalkan kinerja instansi, disamping dapat memberikan kepuasan kepada rakyat.

\section{Anggaran}

Anggaran adalah pernyataan tentang estimasi kinerja yang akan dicapai selama periode tertentu dan dinyatakan dalam ukuran finansial sedangkan penganggaran adalah proses atau metode untuk mempersiapkan suatu anggaran. Penganggaran sektor publik terkait dengan proses jumlah alokasi dana untuk suatu program atau kegiatan (Mardiasmo, 2002:62). Anggaran dalam pengertian lain dapat dikatakan sebagai rencana finansial yang menyatakan rencana organisasi dalam melayani masyarakat atau aktivitas lain yang dapat mengembangkan kapasitas organisasi dalam pelayanan, estimasi besarnya biaya yang harus dikeluarkan dalam merealisasikan rencana, perkiraan sumber yang akan menghasilkan pemasukan serta seberapa besar pemasukan (Nordiawan, 2006). Anggaran sektor publik merupakan alat ekonomi terpenting yang dimiliki pemerintah untuk mengarahkan perkembangan sosial dan ekonomi, menjamin kesinambungan dan meningkatkan kualitas hidup masyarakat sehingga anggaran sektor publik harus memenuhi kriteria :

1. Merefleksikan perubahan prioritas kebutuhan dan keinginan masyarakat

2. Menentukan penerimaan dan pengeluaran departemen-departemen pemerintah, pemerintah provinsi atau pemerintah daerah. 
3. Anggaran juga dapat digunakan sebagai sarana untuk meyakinkan bahwa pemerintah telah bertanggung jawab terhadap rakat sehingga merupakan instrumen pelaksanaan akuntabilitas publik oleh lembaga-lembaga publik yang ada. Dalam anggaran sektor publik, aspek-aspek yang perlu diperhatikan yaitu :

1. Aspek perencanaan

2. Aspek pengendalian

3. Aspek akuntabilitas publik

Menurut (Bastian, 2014) prinsip-prinsip penganggaran sektor publik meliput :

a. Demokratis yaitu anggaran baik yang berkaitan dengan pendapatan maupun pengeluaran haruslah ditetapkan melalui proses mengikutsertakan sebanyak mungkin unsur masyarakat.

b. Adil artinya anggaran diarahkan secara optimum bagi kepentingan orang banyak dan secara ukurannya dialokasikan bagi semua kelompok masyarakat sesuai dengan kebutuhannya.

c. Transparan yaitu proses perencanaan, pelaksanaan serta pertanggungjawaban anggaran harus diketahui oleh masyarakat.

d. Bermoral tinggi yaitu pengelolaan anggaran berpegang teguh pada peraturan perundangan yang berlaku dan senantiasa mengacu pada etika dan moral yang tinggi.

e. Berhati-hati, pengelolaan anggaran kesehatan harus dilakukan secara berhati-hati karena posisi sumber daya jumlahnya terbatas dan mahal harganya.

f. Akuntanbel yaitu pengelolaan keuangan oganisasi sektor publik dapat dipertanggungjawabkan setiap saat secara internal maupun eksternal kepada rakyat.

\section{Anggaran Berbasis Kinerja}

Anggaran Berbasis Kinerja adalah sistem penganggaran yang berorientasi pada output organisasi dan berkaitan sangat erat terhadap Visi, Misi dan Rencana Strategis organisasi. Anggaran Berbasis Kinerja mengalokasikan sumberdaya pada program bukan pada unit organisasi semata dan memakai .output measurement. sebagai indikator kinerja organisasi (Mardiasmo, 2002:70).

Anggaran Berbasis Kinerja pada pemerintah daerah pertama sekali digulirkan dengan terbitnya Keputusan Menteri Dalam Negeri Nomor 29 Tahun 2002 yang berisi panduan untuk membuat anggaran kinerja, pelaksanaan anggaran sampai dengan pelaporan pelaksanaan anggaran. Regulasi ini kemudian disempurnakan dengan diterbitkannya Peraturan Menteri Dalam Negeri Nomor 13 Tahun 2006 dan terakhir 
dengan diterbitkannya Peraturan Menteri Dalam Negeri Nomor 59 Tahun 2007 sebagai penjabaran lebih lanjut dari Peraturan Pemerintah Nomor 58 Tahun 2005.

Berdasarkan Peraturan Pemerintah Nomor 58 Tahun 2005, maka penyusunan APBD dilakukan dengan mengintegrasikan program dan kegiatan masing-masing satuan kerja di lingkungan pemerintah daerah untuk mencapai sasaran dan tujuan yang ditetapkan di dalam dokumen perencanaan. Dengan demikian tercipta sinergi dan rasionalitas yang tinggi dengan mengalokasikan sumber daya yang terbatas untuk memenuhi kebutuhan masyarakat yang tidak terbatas. Hal tersebut juga untuk menghindari duplikasi rencana kerja serta bertujuan untuk meminimalisasi kesenjangan antara target dengan hasil yang dicapai berdasarkan tolok ukur kinerja yang telah ditetapkan.

Penganggaran berbasis kinerja ini berfokus pada efisiensi penyelenggaraan suatu aktivitas atau kegiatan. Efisiensi itu sendiri adalah perbandingan antara output dengan input. Suatu aktivitas dikatakan efisien, apabila output yang dihasilkan lebih besar dengan input yang sama, atau output yang dihasilkan adalah sama dengan input yang lebih sedikit. Anggaran ini tidak hanya didasarkan pada apa yang dibelanjakan saja, seperti yang terjadi pada sistem anggaran tradisional, tetapi juga didasarkan pada tujuan/rencana tertentu yang pelaksanaannya perlu disusun atau didukung oleh satu anggaran biaya yang cukup dan terukur juga penggunaan biaya tersebut harus efisien dan efektif.

Berbeda dengan penganggaran dengan pendekatan tradisional, penganggaran dengan pendekatan kinerja ini disusun dengan orientasi output. Jadi, apabila kita menyusun anggaran dengan pendekatan kinerja, maka mindset kita harus fokus pada "apa yang ingin dicapai". Kalau fokus ke "output", berarti pemikiran tentang "tujuan" kegiatan harus sudah tercakup di setiap langkah ketika menyusun anggaran. Sistem ini menitikberatkan pada segi penatalaksanaan sehingga selain efisiensi penggunaan dana juga hasil kerjanya diperiksa. Jadi, tolok ukur keberhasilan sistem anggaran ini adalah performance atau prestasi dari tujuan atau hasil anggaran dengan menggunakan dana secara efisien. Dengan membangun suatu sistem penganggaran yang dapat memadukan perencanaan kinerja dengan anggaran tahunan akan terlihat adanya keterkaitan antara dana yang tersedia dengan hasil yang diharapkan.

Penyusunan APBD berbasis kinerja dilakukan berdasarkan capaian kinerja, indikator kinerja, analisis standar belanja, standar satuan harga, dan standar pelayanan minimal. Penyelenggaraan urusan pemerintahan dibagi berdasarkan kriteria eksternalitas, akuntabilitas, dan efisiensi dengan memperhatikan keserasian hubungan antar susunan 
pemerintahan. Dalam penyelenggaraannya, pemerintah daerah dituntut lebih responsif, transparan, dan akuntabel terhadap kepentingan masyarakat (Mardiasmo, 2006).

Indikator kinerja yang ditetapkan dalam penyusunan anggaran berbasis kinerja meliputi masukan (input), keluaran (output) dan (outcome). Masukan (input) adalah segala sesuatu yang dibutuhkan agar pelaksanaan kegiatan dapat berjalan untuk menghasilkan keluaran. Indikator ini merupakan tolok ukur kinerja berdasarkan tingkat atau besaran sumber-sumber dana, sumber daya manusia, material, waktu, teknologi, dan sebagainya yang digunakan untuk melaksanakan program atau kegiatan. Dengan meninjau distribusi sumber daya, suatu organisasi dapat menganalisis apakah alokasi sumber daya yang dimiliki telah sesuai dengan rencana strategik yang telah ditetapkan.

Keluaran (output) adalah produk berupa barang atau jasa yang dihasilkan dari program atau kegiatan sesuai dengan masukan yang digunakan. Indikator keluaran adalah sesuatu yang diharapkan langsung dicapai dari suatu kegiatan yang dapat berupa fisik dan/atau non fisik. Dengan membandingkan indikator keluaran organisasi dapat menganalisis sejauh mana kegiatan terlaksana sesuai dengan rencana. Indikator keluaran hanya dapat menjadi landasan untuk menilai kemajuan suatu kegiatan apabila tolok ukur dikaitkan dengan sasaran-sasaran kegiatan yang terdefinisi dengan baik dan terukur. Oleh karenanya indikator keluaran harus sesuai dengan lingkup dan sifat kegiatan instansi.

Hasil (outcome) adalah segala sesuatu yang mencerminkan berfungsinya keluaran kegiatan pada jangka menengah (efek langsung). Indikator hasil adalah sesuatu manfaat yang diharapkan diperoleh dari keluaran. Tolok ukur ini menggambarkan hasil nyata dari keluaran suatu kegiatan. Pada umumnya para pembuat kebijakan paling tertarik pada tolok ukur hasil dibandingkan dengan tolok ukur lainnya. Namun untuk mengukur indikator hasil, informasi yang diperlukan seringkali tidak lengkap dan tidak mudah diperoleh. Oleh karenanya setiap organisasi perlu mengkaji berbagai pendekatan untuk mengukur hasil dari keluaran satu kegiatan.

\section{E-Budgeting}

\section{Pengertian E-Budgeting}

Sistem E-Budgeting adalah bagian awal dari skenario besar e-Government di Pemerintah Kota Surabaya, melalui konsep GRMS (Government Resource Management System). Sistem E-Budgeting adalah sistem penyusunan anggaran yang didalamnya termasuk aplikasi program komputer berbasis web untuk memfasilitasi proses penyusunan APBD 
(Anggaran Pendapatan dan Belanja Daerah), Revisi, dan PAK (Perubahan Anggaran Kegiatan) Pemerintah Kota Surabaya.

\section{Tujuan E-Budgeting}

Memberikan panduan dalam proses penyusunan APBD, revisi dan PAK (Perubahan Anggaran Kegiatan) di Pemerintah Kota Surabaya.

\section{Ruang Lingkup}

1. Penyusunan Standar Satuan Harga (SSH), Harga Satuan Pokok Kegiatan (HSPK), Analisa Standar Belanja (ASB).

2. Penyusunan Rencana Kerja dan Anggaran (RKA) sehingga menjadi Dokumen Pelaksanaan Anggaran (DPA).

\section{Revisi DPA SKPD}

4. Penyusunan Perubahan APBD (PAK)

\section{Definisi}

1. Anggaran Pendapatan dan Belanja Daerah, selanjutnya disingkat APBD adalah rencana keuangan tahunan pemerintahan daerah yang dibahas dan disetujui bersama oleh pemerintah daerah dan DPRD, dan ditetapkan dengan peraturan daerah.

2. Satuan Kerja Perangkat Daerah adalah perangkat daerah pada pemerintah daerah selaku pengguna anggaran/pengguna barang.

3. Satuan Kerja Pengelola Keuangan Daerah adalah perangkat daerah pada pemerintah daerah selaku pengguna anggaran/pengguna barang, yang juga melaksanakan pengelolaan keuangan daerah.

4. Pejabat Pengelola Keuangan Daerah adalah kepala satuan kerja pengelola keuangan daerah yang selanjutnya disebut dengan kepala SKPKD yang mempunyai tugas melaksanakan pengelolaan APBD dan bertindak sebagai bendahara umum daerah.

5. Rencana Pembangunan Jangka Menengah Daerah yang selanjutnya disingkat RPJMD adalah dokumen perencanaan untuk periode 5 (lima) tahun.

6. Rencana Kerja Pemerintah Daerah (RKPD) adalah dokumen perencanaan Daerah untuk periode 1 tahun.

7. Tim Anggaran Pemerintah Daerah (TAPD) adalah tim yang dibentuk dengan keputusan kepala daerah dan dipimpin oleh sekretaris daerah yang mempunyai tugas menyiapkan serta melaksanakan kebijakan kepala daerah dalam rangka 
penyusunan APBD yang anggotanya terdiri dari pejabat perencana daerah, PPKD dan pejabat lainnya sesuai dengan kebutuhan.

8. Kebijakan Umum APBD yang selanjutnya disingkat KUA adalah dokumen yang membuat kebijakan bidang pendapatan, belanja, dan pembiayaan serta asumsi yang mendasarnya untuk periode 1 tahun.

9. Prioritas dan Plafon Anggaran Sementara yang selanjutnya disingkat PPAS adalah rancangan program prioritas dan patokan batas maksimal anggaran yang diberikan kepada SKPD untuk setiap program sebagai acuan dalam penyusunan RKA-SKPD sebelum disepakati dengan DPRD.

10. Prioritas dan Plafon Anggaran yang selanjutnya disingkat PPA adalah program prioritas dan patokan batas maksimal anggaran yang diberikan kepada SKPD untuk setiap program sebagai acuan dalam penyusunan RKA-SKPD setelah disepakati dengan DPRD.

11. Rencana Kerja dan Anggaran SKPD disingkat RKA-SKPD adalah dokumen perencanaan dan penganggaran yang berisi rencana pendapatan, rencana belanja program dan kegiatan SKPD serta rencana pembiayaan sebagai dasar penyusunan APBD.

12. Kegiatan adalah bagian dari program yang dilaksanakan oleh satu atau lebih unit kerja pada SKPD sebagai bagian dari pencapaian sasaran terukur pada suatu program dan terdiri dari sekumpulan tindakan pengerahan sumber daya baik yang berupa personil (Sumber Daya Manusia), barang modal termasuk peralatan dan teknologi, dana, atau kombinasi dari beberapa atau kesemua jenis sumber daya tersebut sebagai masukan (input) untuk menghasilkan keluaran (output) dalam bentuk barang/jasa.

13. Sasaran (target) adalah hasil yang diharapkan dari suatu program atau keluaran yang diharapkan dari suatu kegiatan.

14. Keluaran (output) adalah barang atau jasa yang dihasilkan oleh kegiatan yang dilaksanakan untuk mendukung pencapaian sasaran dan tujuan program dan kebijakan.

15. Hasil (outcome) adalah segala sesuatu yang mencerminkan berfungsinya keluaran dari kegiatan-kegiatan dalam satu program.

16. Pendapatan Daerah adalah hak pemerintah daerah yang diakui sebagai penambah nilai kekayaan bersih. 
17. Dokumen Pelaksanaan Anggaran SKPD yang selanjutnya disingkat DPA-SKPD adalah dokumen yang memuat pendapatan, belanja dan pembiayaan yang digunakan sebagai dasar pelaksanaan anggaran oleh PA/KPA pada Sekretariat Daerah.

18. Dokumen Pelaksanaan Perubahan Anggaran SKPD yang selanjutnya disingkat DPPA-SKPD adalah dokumen yang memuat perubahan pendapatan, belanja dan pembiayaan yang digunakan sebagai dasar pelaksanaan perubahan anggaran oleh PA/KPA pada Sekretariat Daerah.

19. Bappeko atau Badan Perencanaan Pembangunan Kota adalah salah satu tim anggaran yang bertugas untuk mengisikan kegiatan, target output, nilai pagu dan sub title dalam kegiatan untuk masing-masing SKPD.

20. Tim Data adalah tim data pada Bagian Bina Program yang bertanggungjawab terhadap kegiatan input, update dan delete data SSH, HSPK, ASB dan estimasi.

21. Penyelia adalah penyelia pada Bappeko, Bagian Bina Program dan DPPK yang bertugas mendampingi SKPD dalam penyusunan anggaran.

22. Admin adalah staf di Bagian Bina Program yang bertanggungjawab terhadap pengelolaan data dan ketersediaan data dalam menunjang proses penyusunan anggaran.

23. SSH (Standar Satuan Harga) adalah harga setiap unit baran/jasa yang berlaku disuatu daerah (Permendagri No 13/2006 Pasal 93 ayat (5) sebagaimana telah diubah kedua kali dengan Permendagri No 21/2011).

24. HSPK atau Harga Satuan Pokok Kegiatan adalah merupakan harga komponen kegiatan fisik/non fisik melalui analisis yang distandarkan untuk setiap jenis komponen kegiatan dengan menggunakan SSH sebagai elemen penyusunannya.

25. ASB atau Analisa Standar Belanja adalah merupakan penilaian kewajaran atas beban kerja dan biaya yang digunakan untuk melaksanakan suatu kegiatan (Permendagri No 13 Tahun 2006 Pasal 93 ayat 4 sebagaimana telah diubah kedua kali dengan Permendagri No 21 Tahun 2011).

\section{Alur Proses Penyusunan Anggaran}

Berdasarkan Website resmi Pemerintah Kota Surabaya dalam langkah-langkah penyusunan sistem $e$-budgting, antara lain :

1. Dengan sudah adanya RPJM dalam kurun 5 (lima) tahun, maka pada saat akan melakukan penyusunan APBD, terlebih dahulu disusun RKPD yang merupakan penjabaran dari RPJM dengan menggunakan Rencana Kerja Satuan Kerja 
Perangkat Daerah (Renja SKPD) untuk jangka waktu 1 (satu) tahun yang berdasarkan pada Rencana Kerja Pemerintah.

2. Bappeko melakukan koordinasi rencana pembangunan dengan kelurahan, kecamatan dan kota melalui musrenbang, yang dilaksanakan pada awal tahun.

3. Berdasarkan RKPD dan Peraturan Menteri Dalam Negeri terkait dengan Pengelolaan Keuangan Daerah, maka Walikota dibantu TAPD yang dipimpin oleh Sekretaris Daerah menyusun KUA

4. Rancangan KUA disampaikan ke DPRD untuk dibahas dan dimintakan persetujuan dalam pembicaraan pendahuluan RAPBD.

5. Setelah rancangan KUA disetujui, selanjutnya disusun PPAS, untuk dibahas bersama TAPD dengan panitia anggaran DPRD dalam rapat Badan Anggaran DPRD

6. Rancangan PPAS yang telah disepakati selanjutnya menjadi PPA.

7. KUA dan PPA yang telah disepakati, dituangkan dalam Nota Kesepakatan antara DPRD dan Walikota

8. Berdasarkan Nota Kesepakatan terkait KUA dan PPA, Walikota mengeluarkan Surat Edaran (SE) tentang Pedoman Penyusunan Rencana Kerja dan Anggaran SKPD (RKA-SKPD) sebagai acuan SKPD dalam menyusun RKA-SKPD.

9. Penyusunan SSH, HSPK, ASB

a. Penyusunan SSH

Tim Survey melakukan survey harga pasar dari 3 (tiga) tempat yang berbeda (bisa dari internet, toko di daerah surabaya utara, surabaya selatan, surabaya timur, surabaya barat) maksimal 2 (dua) bulan sebelum proses penyusunan anggaran dimulai.

Lalu data hasil survey, dibahas dan dikaji oleh tim survey bersama dengan tenaga ahli dan tim penyusunan dan pelaksanaan program untuk menentukan harga yang dipakai.

b. Penyusunan HSPK

HSPK disusun dengan berdasarkan pada komponen - komponen SSH yang sudah di lock dalam aplikasi dengan mengacu pada standart yang ada (antara lain SNI, AHSP Kementrian PU).

Dalam 1 (satu) HSPK akan terdiri dari beberapa komponen SSH sebagai penunjang kegiatan yang dimaksud dan dikalikan dengan volume yang dibutuhkan. 


\section{c. Penyusunan ASB}

ASB Fisik disusun atas kumpulan HSPK (disesuaikan dengan kebutuhan paket pekerjaan). ASB Non Fisik, misalnya pelatihan, sosialisasi, bimbingan teknis, seminar disusun berdasarkan komponen-komponen SSH yang disesuaikan dengan kebutuhan secara minimal kegiatan yang dilakukan. ASB OM (operasional maintenance / pemeliharaan), disusun dari beberapa SSH sesuai kebutuhan.

10. Penyusunan RKA / DPA

a. Bagian Bina Program menyiapkan aplikasi eBudgeting termasuk komponen SSH yang akan digunakan dan ditetapkan dengan Keputusan Walikota Surabaya

b. Bappeko mengisikan kegiatan, target output untuk tiap - tiap kegiatan, nilai pagu dan subtitle dari tiap kegiatan untuk semua SKPD maksimal 1 (satu) minggu sebelum SE beredar

c. TAPD membuat dan mengirimkan Surat Edaran (SE) ketua TAPD terkait dengan waktu mulai penyusunan RKA maksimal 2 (dua) minggu sebelum penyusunan anggaran dimulai.

d. SKPD mulai mengisikan RKA untuk tiap - tiap kegiatan dengan subtitle yang telah ditetapkan, dan nilai pagu tidak boleh melebihi pagu yang ditetapkan Bappeko, sejak SE diterima sampai dengan 1 (satu) minggu setelah waktu mulai.

e. Penyelia sebagai pendamping SKPD secara paralel melakukan pengecekan kesesuaian isi RKA yang telah dientrikan oleh SKPD dengan ketentuan ketentuan yang harus dipenuhi, dan memberikan masukan, saran kepada SKPD jika menemukan sesuatu yang tidak sesuai agar dilakukan pembetulan, sejak SKPD mengentrikan RKA sampai dengan 2 (dua) minggu setelahnya. Raperda APBD yang telah disusun, disampaikan oleh PPKD kepada DPRD untuk dilakukan pembahasan bersama. Dan sampai dengan proses pembahasan di DPRD, penyelia ikut mendampingi SKPD dalam mempertanggungjawabkan isian RKA,

f. RKA SKPD dibahasi di komisi DPRD, kemudian dilanjutkan ke Badan Musyawarah (Banmus) DPRD.

g. Setelah proses di Banmus selesai, dilanjutkan di Badan Anggaran (Banggar) , yang mana pada Banggar ini melibatkan legislatif (DPRD) dan eksekutif 
(Pemerintah Kota Surabaya) dalam rangka proses perangkaan sebagai bahan paripurna dalam penyusunan RAPERDA APBD.

h. Setelah itu RAPERDA APBD dikirim ke Propinsi untuk dievaluasi sebelum di PERDA kan sehingga menjadi DPA.

11. Revisi / Pergeseran APBD

a. Disebabkan karena adanya perubahan aturan, kebijakan baru dari pemerintah pusat yang berpengaruh pada kebijakan pemerintah daerah.

b. Adanya kesalahan rekening pada DPA SKPD.

c. Usulan perubahan dari SKPD.

d. Revisi boleh dilakukan selama tidak antar belanja dan total belanja tidak boleh berubah.

e. Memungkinkan adanya SSH dan HSPK baru yang diusulkan SKPD dan dientrikan oleh tim data ke dalam aplikasi agar nantinya dapat digunakan SKPD dalam penyusunan revisi.

f. Bagian Bina Program menyiapkan aplikasi eBudgeting termasuk komponen SSH yang akan digunakan dan ditetapkan dengan Keputusan Walikota Surabaya.

g. Usulan dari SKPD dikumpulkan oleh TAPD, kemudian dilakukan pembahasan terhadap usulan dari SKPD tersebut.

h. Setelah analisa usulan revisi dibahas oleh TAPD, selanjutnya dibuatkan resume yang menjelaskan usulan revisi mana yang diijinkan dan tidak diijinkan beserta alasannya, serta waktu mulai penyusunan revisi.

i. Hasil pembahasan antara TAPD dengan SKPD berupa resume yang menjadi dasar bagi penyelia untuk melakukan konfirmasi buka kegiatan agar selanjutnya SKPD dapat melakukan entri revisi.

j. SKPD melakukan proses revisi dalam aplikasi berdasarkan hasil resume.

k. Penyelia sebagai pendamping SKPD melakukan pengecekan terhadap hasil entri revisi yang dilakukan SKPD pada aplikasi eBudgeting.

12. Penyusunan Perubahan Anggaran Kegiatan (PAK)

a. PAK dilakukan karena adanya perubahan aturan, evaluasi BPK (Badan Pemeriksa Keuangan), dan sebab lainnya yang mengharuskan dilakukan perubahan anggaran, sesuai dengan Pasal 154 Permendagri No 13/2006 sebagaimana telah diubah kedua kali dengan Permendagri No 21/2011. 
b. Dalam proses PAK, memungkinkan adanya SSH dan HSPK baru, penambahan atau pengurangan kegiatan.

c. Bagian Bina Program menyiapkan aplikasi eBudgeting termasuk komponen SSH yang akan digunakan dan ditetapkan dengan Keputusan Walikota Surabaya

d. Bappeko mengisikan kegiatan baru, target output untuk tiap - tiap kegiatan, nilai pagu dan subtitle dari tiap kegiatan untuk semua SKPD maksimal 3 (tiga) minggu sebelum SE beredar

e. SKPD mulai mengisikan PAK untuk tiap - tiap kegiatan dengan subtitle yang telah ditetapkan, dan nilai pagu tidak boleh melebihi pagu yang ditetapkan Bappeko, sejak SE diterima sampai dengan 1 (satu) minggu setelah waktu mulai.

f. Penyelia sebagai pendamping SKPD secara paralel melakukan pengecekan kesesuaian PAK yang telah dientrikan oleh SKPD dengan ketentuan ketentuan yang harus dipenuhi, dan memberikan masukan, saran kepada SKPD jika menemukan sesuatu yang tidak sesuai agar dilakukan pembetulan, sejak SKPD mengentrikan data PAK sampai dengan 2 (dua) minggu setelahnya. Raperda perubahan APBD yang telah selesai dilakukan pembahasan dan proses entry ke eBudgeting dicetak untuk kemudian disampaikan pada DPRD dan dilakukan pembahasan bersama. Dan sampai dengan proses pembahasan di DPRD, penyelia ikut mendampingi SKPD dalam mempertanggungjawabkan isian data PAK.

g. Data PAK dipertanggungjawabkan di tiap komisi DPRD, kemudian dilanjutkan ke Badan Musyawarah (Banmus) DPRD.

h. Setelah proses di Banmus selesai, dilanjutkan di Badan Anggaran (Banggar) yang mana pada Banggar ini melibatkan legislatif (DPRD) dan eksekutif (Pemerintah Kota Surabaya) dalam rangka proses perangkaan sebagai bahan paripurna dalam penyusunan RAPERDA APBD - Perubahan.

i. Setelah itu RAPERDA APBD - Perubahan dikirim ke Propinsi untuk dievaluasi sebelum di PERDA kan sehingga menjadi DPA - Perubahan. 


\section{Tranparansi}

\section{Pengertian Transparansi}

Yang dimaksud dengan konsep transparansi dalam penelitian ini adalah terbukanya akses bagi masyarakat dalam memperoleh informasi mengenai perencanaan, pelaksanaan, pengawasan dan pertanggungjawaban Sistem E-Budgeting. Hal ini didasarkan pada pendapat beberapa ahli, yaitu sebagai berikut.

Mardiasmo (2002:31) menyebutkan transparansi adalah keterbukaan pemerintah dalam memberikan informasi yang terkait dengan aktifitas pengelolaan sumber daya publik kepada pihak yang membutuhkan yaitu masyarakat. Tujuan transparansi dalam penyelenggaraan pemerintahan desa yaitu :

1. Salah satu wujud pertanggungjawaban pemerintah kepada

2. masyarakat

3. Upaya peningkatan manajemen pengelolaan pemerintahan

4. Upaya peningkatan manajemen pengelolaan dan penyelenggaraan pemerintahan yang baik dan mengurangi kesempatan praktek KKN.

Transparansi akan memberikan dampak positif dalam tata pemerintahan. Transparansi akan meningkatkan pertanggungjawaban para perumus kebijakan sehingga kontrol masyarakat terhadap para pemegang otoritas pembuat kebijakan akan berjalan efektif.

\section{Prinsip- prinsip Transparansi}

Setidaknya ada 6 prinsip transparansi yang dikemukakan oleh Humanitarian Forum Indonesia (HFI) yaitu :

1. Adanya informasi yang mudah dipahami dan diakses (dana, cara pelaksanaan, bentuk bantuan atau program)

2. Adanya publikasi dan media mengenai proses kegiatan dan detail keuangan.

3. Adanya laporan berkala mengenai pendayagunaan sumber daya dalam perkembangan proyek yang dapat diakses oleh umum.

4. Laporan tahunan

5. Website atau media publikasi organisasi

6. Pedoman dalam penyebaran informasi

Mustopadidjaya (2002:261), prinsip transparansi tidak hanya berhubungan dengan hal-hal yang menyangkut keuangan, transparansi pemerintah dalam perencanaan juga meliputi 5 (lima) hal sebagai berikut : 
1. Keterbukaaan dalam rapat penting dimana masyarakat ikut memberikan pendapatnya.

2. Keterbukaan Informasi yang berhubungan dengan dokumen yang perlu diketahui oleh masyarakat.

3. Keterbukaan prosedur (pengambilan keputusan atau prosedur penyusunan rancana)

4. Keterbukaan register yang berisi fakta hukum (catatan sipil, buku tanah dll.)

5. Keterbukaan menerima peran serta masyarakat.

Mardiasmo (2006:52) menyebutkan bahwa transparansi anggaran adalah informasi terkait perencanaan penganggaran merupakan hak setiap masyarakat. Hak masyarakat yang terkait penganggaran yaitu:

a. Hak untuk mengetahui

b. Hak untuk mengamati dan menghadiri pertemuan

Publik

c. Hak untuk mengemukakan pendapat

d. Hak untuk memperoleh dokumen publik

e. Hak untuk diberi informasi

Berdasarkan penjelasan tersebut, beberapa prinsip yang dimaksud dalam penelitian ini antara lain, adanya keterbukaan informasi yang mudah dipahami oleh masyarakat, adanya publikasi mengenai detail keuangan Anggaran, adanya laporan berkala mengenai pengelolaan Anggaran tersebut yang dilakukan pemerintah kota Surabaya kepada masyarakat. Prinsip transparansi menciptakan kepercayaan timbal balik antara masyarakat dan pemerintah melalui penyediaan informasi yang akurat dan memadai. Transparansi akan mengurangi tingkat ketidakpastian dalam proses pengambilan keputusan mengenai pengelolaan dana desa, karena penyebarluasan berbagai informasi yang selama ini aksesnya hanya dimiliki pemerintah dapat memberikan kesempatan kepada masyarakat untuk turut mengambil keputusan, misalnya dengan rapat desa yang dilakukan secara musyawarah. Selain itu, transparansi dapat mempersempit peluang korupsi dalam lingkup pemerintah desa dengan masyarakat ikut berpartisipasi dalam pengambilan keputusan tersebut.

Aspek mekanisme pengelolaan anggaran harus dilakukan secara transparansi, ada hal-hal yang perlu diketahui yaitu (Tahir, 2011:163) :

1. Penetapan posisi jabatan

2. Kekayaan pejabat publik

3. Pemberian penghargaan 
4. Penetapan kebijakan

5. Kesehatan

6. Moralitas para pejabat dan aparatur pelayanan publik

Transparansi merupakan nilai utama dari sistem pemerintahan. Konteks utama aktivitas pemerintah harus diyakini berdasarkan pada transparansi. Terdapat kekuatan publik yang menuntut transparansi yang lebih besar. Pada hakekat nya dengan percepatan dan pengaruh terhadap organisasi swasta, sebagaimana terus meningkatnya pepulasi masyarakat. Ini berarti tuntutan publik terhadap transparansi sudah semakin kuat. (Tahir, 2011:164) mengemukakan bahwa proses transparansi meliputi :

1. Standard procedural requirements (Persyaratan Standar Prosedur), bahwa proses pembuatan peraturan harus melibatkan partisipasi dan memperhatikan kebutuhan masyarakat.

2. Consultation processes (Proses Konsultasi), Adanya dialog antara pemerintah dan masyarakat

3. Appeal rights (Permohonan Izin), adalah pelindung utama dalam proses pengaturan. Standard dan tidak berbelit, transparan guna menghindari adanya korupsi

\section{Indikator Transparansi}

Mardiasmo (2006:73) menyebutkan bahwa transparansi dapat diukur melalui beberapa indikator :

1. Kesediaan dan aksesibilitas dokumen

2. Kejelasan dan kelengkapan informasi

3. Keterbukaan proses

4. Kerangka regulasi yang menjamin transparansis

Transparansi merujuk pada ketersediaan informasi pada masyarakat umum dan kejelasan tentang peraturan perundang-undangan dan keputusan pemerintah, dengan indikator sebagai berikut :

a. Akses pada informasi yang akurat dan tepat waktu

b. Penyediaan informasi yang jelas tentang prosedur dan biaya

c. Kemudahan akses informasi

d. Menyusun suatu mekanisme pengaduan jika terjadi pelanggaran 
Berdasarkan indikator-indikator yang telah dijelaskan diatas, indicator prinsip transparansi dalam penelitian ini adalah :

a. Penyediaan dan akses informasi yang jelas tentang perencanaan, prosedur pelaksanaan dan pertanggungjawaban

b. Adanya musyawarah yang melibatkan masyarakat

c. Keterbukaan proses pengelolaan

d. Keterbukaan informasi pengelolaan sistem E-Budgeting tentang dokumen

Keberhasilan transparansi suatu lembaga ditunjukkan oleh indikator (Adrianto, 2007:21) sebagai berikut :

1. Ada tidaknya kerangka kerja hukum bagi transparansi

a. Adanya peraturan perundang-undangan yang mengatur persoalan transparansi

b. Adanya kerangka kerja hukum yang memberi definisi yang jelas tentang peran dan tanggung jawab bagi semua aspek kunci dari manajemen fiskal.

c. Adanya basis legal untuk pajak

d. Adanya basis legal untuk pertanggungjawaban belanja dan kekuasaan memungut pajak dari pemerintah daerah

e. Adanya pembagian peran dan tanggung jawab yang jelas dari masing-masing tingkatan pemerintah

2. Adanya akses masyarakat terhadap transparansi anggaran.

a. Adanya keterbukaan dalam kerangka kerja anggaran (proses anggaran)

b. Diumumkannya setiap kebijakan anggaran

c. Dipublikasikannya setiap hasil laporan anggaran (yang teah diaudit oleh lembaga yang berwenang)

d. Adanya dokumentasi anggaran yang baik yang mengandung beberapa indikasi fiskal

e. Terbukanya informasi tentang pembelanjaan aktual

3. Adanya audit yang independen dan efektif

a. Adanya lembaga audit yang independen dan efektif

b. Adanya kantor statistik yang akurasi datanya berkualitas

c. Adanya sistem peringatan dini (early warning system) dalam kasus buruknya eksekusi atau keputusan anggaran

4. Adanya keterlibatan masyarakat dalam pembuatan keputusan anggaran

a. Adanya keterbukaan informasi selama proses penyusunan anggaran 
b. Adanya kesempatan bagi masyarakat sipil untuk berpartisipasi dalam proses penganggaran

Sutedi (2009:400) Indikator transparansi dalam model pengukuran pelaksanaan Good Governance :

a. Mekanisme yang menjamin sistem keterbukaan dan standarisasi dari semua proses pelayanan publik.

b. Mekanisme yang memfasilitasi pertanyaan-pertanyaan publik tentang berbagai kebijakan dan pelayanan publik, maupun proses-proses di dalam sektor publik.

c. Mekanisme yang memfasilitasi pelaporan maupun penyebaran informasi maupun penyimpangan tindakan aparat publik di dalam melayani kegiatan.

d. Ketersediaan payung hukum bagi akses informasi publik

e. Ketersediaan mekanisme bagi publik untuk mengakses informasi

f. Ketersediaan sarana dan prasarana untuk mengakses informasi publik

g. Ketersediaan informasi untuk dipublikasikan kepada publik

h. Kecepatan dan kemudahan mendapatkan informasi publik

\section{Akuntabilitas}

\section{Pengertian Akuntabilitas}

Yang dimaksud konsep akuntabilitas dalam penelitian ini yaitu pertanggungjawaban tim pelaksna pengelolaan Anggaran kepada masyarakat, dimana Bagian Administrasi Pembangunan sebagai penanggungjawab utama dan pembuat sistem. Konsep ini didasarkan pada pendapat beberapa ahli antara lain :

Syahrudin (2003:8) akuntabilitas adalah kemampuan memberi jawaban kepada otoritas yang lebih tinggi atas tindakan seseorang atau sekelompok orang terhadap masyarakat luas dalam suatu organisasi. Akuntabilitas yakni para pengambil keputusan dalam organisasi sector publik, swasta serta masyarakat madani memiliki pertanggungjawaban (akuntabilitas) kepada publik (masyarakat umum) sebagaimana halnya pada pemilik kepentingan.

Dalam pasal 7 Undang- Undang No.28 tahun 1999 menjelaskan bahwa yang dimaksud asas akuntabilitas adalah asas yang menentukan bahwa setiap kegiatan dan hasil dari kegiatan penyelenggaraan negara harus dapat dipertanggungjawabkan kepada masyarakat / rakyat sebagai pemegang kedaulatan tertinggi negara sesuai dengan ketentuan peraturan perundang-undangan yang berlaku. 
Menurut UNDP, akuntabilitas adalah evaluasi terhadap proses pelaksanaan kegiatan/kinerja organisasi untuk dapat dipertanggungjawabkan serta sebagai umpan balik bagi pimpinan organisasi untuk dapat lebih meningkatkan kinerja organisasi pada masa yang akan datang. Akuntabilitas dapat diperoleh melalui:

1. Usaha untuk membuat para aparat pemerintahan mampu bertanggungjawab untuk setiap perilaku pemerintah dan responsive pada identitas dimana mereka memperoleh kewenangan

2. Penetapan kriteria untuk mengukur performan aparat pemerintahan serta penetapan mekanisme untuk menjamin bahwa standar telah terpenuhi.

\section{Dimensi Akuntabilitas}

Dimensi akuntabilitas ada 5, yaitu (Adrianto, 2007:23)

1. Akuntabilitas hukum dan kejujuran (accuntability for probity and legality).

Akuntabilitas hukum terkait dengan dilakukannya kepatuhan terhadap hukum dan peraturan lain yang disyaratkan dalam organisasi, sedangkan akuntabilitas kejujuran terkait dengan penghindaran penyalahgunaan jabatan, korupsi dan kolusi. Akuntabilitas hukum menjamin ditegakkannya supremasi hukum, sedangkan akuntabilitas kejujuran menjamin adanya praktik organisasi yang sehat.

2. Akuntabilitas manajerial.

Akuntabilitas manajerial yang dapat juga diartikan sebagai akuntabilitas kinerja (performance accountability) adalah pertanggungjawaban untuk melakukan pengelolaan organisasi secara efektif dan efisien.

3. Akuntabilitas program

Akuntabilitas program juga berarti bahwa programprogram organisasi hendaknya merupakan program yang bermutu dan mendukung strategi dalam pencapaian visi, misi dan tujuan organisasi.

Lembaga publik harus mempertanggungjawabkan program yang telah dibuat sampai pada pelaksanaan program.

4. Akuntabilitas kebijakan

Lembaga - lembaga publik hendaknya dapat mempertanggung jawabkan kebijakan yang telah ditetapkan dengan mempertimbangkan dampak dimasa depan. Dalam membuat kebijakan harus dipertimbangkan apa tujuan kebijakan tersebut, mengapa kebijakan itu dilakukan. 


\section{Akuntabilitas finansial}

Akuntabilitas ini merupakan pertanggungjawaban lembaga lembaga publik untuk menggunakan dana publik (public money) secara ekonomis, efisien dan efektif, tidak ada pemborosan dan kebocoran dana, serta korupsi. Akuntabilitas financial ini sangat penting karena menjadi sorotan utama masyarakat. Akuntabilitas ini mengharuskan lembaga-lembaga publikuntuk membuat laporan keuangan untuk menggambarkan kinerja financial organisasi kepada pihak luar

Dari pendapat tersebut ada beberapa dimensi akuntabilitas yang dimaksud dalam penelitian ini yaitu pertanggungjawaban hukum kepala desa, pertanggungjawaban kinerja, pertanggungjawaban program, pertanggungjawaban kebijakan dan pertanggungjawaban oleh tim pelaksana atas sistem E-Budgeting.

(Tjokroamidjojo, 2001:45) menyebutkan ada empat jenis akuntabilitas yaitu :

a. Akuntabilitas politik dari pemerintah melalui lembaga perwakilan

b. Akuntabilitas keuangan melalui pelembagaan budget dan pengawasan BPK

c. Akuntabilitas hukum dalam bentuk reformasi hukum dan pengembangan perangkat hukum

d. Akuntabilitas ekonomi dalam bentuk likuiditas dan (tidak) kepailitan dalam suatu pemerintahan yang demokratis bertanggungjawab pada rakyat melaui system perwakilan.

Akuntabilitas dalam penelitian ini yaitu salah satu jenis akuntabilitas keuangan melalui sebuah lembaga, yaitu pemerintahan desa. Akuntabilitas terwujud dalam bentuk pertaggungjawaban laporan pengelolaan Anggaran oleh tim pelaksana I dalam bidang pemerintahan maupun tim lainnya pada bidang pemberdayaan masyarakat.

\section{Aspek-Aspek Akuntabilitas}

Akuntabilitas terdiri dari beberapa aspek antatara lain :

1. Akuntabitas adalah sebuah hubungan

Akuntabilitas adalah komunikasi dua arah sebagaimana yang diterangkan oleh Auditor General Of British Columbia yaitu merupakan sebuah kontrak antara dua pihak.

2. Akuntabilitas berorientasi hasil

Pada stuktur organisasi sektor swasta dan publik saat ini akuntabilitas tidak melihat kepada input ataupun autput melainkan kepada outcome. 
3. Akuntabilitas memerlukan pelaporan

Pelaporan adalah tulang punggung dari akuntabilitas Akuntabilitas itu tidak ada artinya tanpa konsekuensi. Kata kunci yang digunakan dalam mendiskusikan dan mendefinisikan akuntabilitas adalah tanggung jawab. Tanggungjawab itu mengindikasikan kewajiban dan kewajiban datang bersama konsekuensi.

4. Akuntabilitas meningkatkan kinerja

Tujuan dari akuntabilitas adalah untuk meningkatkan kinerja, bukan untuk mencari kesalahan atau memberi hukuman.

Mengenai akuntabilitas dapat dibedakan atas : democratic accountability, profesional accountability, and legal accountability.

a. Democratic Accountability

Akuntabilitas demokratis merupakan gabungan antara administrative dan politic accountability. Menggarkan pemerintah yang akuntabel atas kinerja dan semua kegiatannya kepada pemimpin politik. Pada negara-negara demokratis, menteri pada parlemen. Penyelenggaraan pelayanan publik akuntabel kepada menteri/pimpinan instansi masing-masing.

b. Profesional Accountability

Dalam akuntabilitas profesional, pada umumnya para pakar, profesional dan teknokrat melaksanakan tugas-tugasnya berdasarkan norma-norma dan standar profesinya untuk menentukan public interest atau kepentingan masyarakat.

c. Legal Accountability

Berdasarkan berdasarkan katagori akuntabilitas legal ( hukum ), pelaksana ketentuan hukum disesuaikan dengan kepentingan public goods and public service yang merupakan tuntutan (demand) masyarakat (customer). Dengan akuntabilitas hukum, setiap petugas pelayanan publik dapat diajukan ke pengadilan apabila mereka gagal dan bersalah dalam melaksanakan tugasnya sebagaimana diharapkan masyarakat. Kesalahan dan kegagalan dalam pemberian pelayanan kepada masyarakat akan terlihat pada laporan akuntabilitas legal.

Akuntabilitas dalam penelitian ini termasuk ke dalam legal accountability atau akuntabilitas yang pelaksaannya didasarkan atas hukum, dimana pengelolaan sistem $E$ Budgeting dilakukan sesuai dengan peraturan atau pedoman yang ada dan jika pemerintah desa maupun tim pelaksana E-Budgeting melakukan pelanggaran dalam pengelolaan $E$ Budgeting maka mendapat sanksi sesuai dengan peraturan perundang-undangan yang berlaku. 


\section{Indikator Akuntabilitas}

Indikator minimum akuntabilitas yaitu :

1. Adanya kesesuaian antara pelaksanaan dengan standar prosedur pelaksanaan

2. Adanya sanksi yang ditetapkan atas kesalahan atau

3. kelalaian dalam pelaksanaan kegiatan

4. Adanya output dan outcome yang terukur

Perangkat indikator akuntabilitas yaitu sebagai berikut :

1) Adanya Standart Operating Procedure dalam

2) Penyelenggaraan urusan pemerintahan atau

3) Dalam penyelenggaraan kewenangan/pelaksanaan kebijakan

4) Mekanisme pertanggungjawaban

5) Laporan tahunan

6) Laporan pertanggungjawaban

7) Sistem pemantauan kinerja penyelenggara negara

8) Sistem pengawasan

9) Mekanisme reward and punishment

(Lalolo, 2003:105) akuntabilitas dalam penyelenggaraan pemerintahan terdiri dari beberapa elemen antara lain :

1. Adanya akses publik terhadap laporan yang telah dibuat

2. Penjelasan dan pembenaran terhadap tindakan pemerintah

3. Penjelasan harus dilakukan dalam sebuah forum terbuka

4. Aktor harus memiliki kewajiban untuk hadir.

Indikator keberhasilan akuntabilitas yaitu:

a. Meningkatnya kepercayaan dan kepuasan publik terhadap pengelolaan keuangan oleh pemerintah

b. Timbulnya kesadaran masyarakat tentang hak untuk menilai penyelenggaraan pemerintah

c. Berkurangnya kasus KKN (Korupsi, Kolusi, Nepotisme) di dalam lingkup pemerintah.

Disebutkan oleh Jay M. Shafritz \& E.W Russel (1997:368), indikator akuntabilitas adalah sebagai berikut:

1. Proses pembuatan sebuah keputusan yang dibuat secara tertulis, tersedia bagi warga dan memenuhi standar administrasi yang berlaku. 
2. Akurasi dan kelengkapan informasi yang berhubungan dengan cara-cara mencapai sasaran suatu program

3. Kejelasan dari tujuan yang ingin dicapai

4. Kelayakan dan konsistensi dari target operasional

5. Sistem informasi manajemen dan monitoring hasil.

Berdasarkan indikator-indikator yang telah disebutkan diatas, indikator akuntabilitas dalam penelitian ini adalah sebagai berikut :

a. Tercapainya tujuan dalam pengelolaan sistem E-Budgeting

b. Adanya pengawasan oleh tim pelaksana

c. Adanya laporan pertangungjawaban

d. Adanya keterlibatan aktor publik

\section{METODE}

Metode yang digunakan dalam penelitian ini adalah metode penelitian kualitatif. Pengertian dari metode kualitatif menurut Bogdan dan Taylor adalah prosedur penelitian yang menghasilkan data deskriptif berupa kata-kata tertulis atau lisan dari orang-orang dan perilaku yang dapat diamati (Moleong, 2012:4). tipe penelitian yang digunakan dalam penelitian ini adalah kualitatif. Menurut Moelong (2012:6), "Penelitian kualitatif didasarkan pada upaya membangun pandangan mereka yang diteliti yang rinci, dibentuk dengan kata-kata, gambaran holistik dan rumit". Penelitian deskriptif kualitatif merupakan penelitian yang bertujuan untuk mendeskripsikan dan menjelaskan segala fenomena secara mendalam yang terjadi di lapangan pada saat penelitian. Lokasi dalam penelitian ini di 20 SKPD Surabaya, mengingat tujuan dari penelitian ini ialah untuk mendefinisikan dan menemukan suatu jawaban atas pertanyaan-pertanyaan penelitian. Kota Surabaya merupakan salah satu daerah yang telah melaksanakan transparansi informasi yang diberikan kepada publik melalui sistem e-budgeting.Sistem elektronik anggaran ini bertujuan untuk diberikan kepada masyarakat yang berkepentingan untuk mengetahui informasi anggaran instansi pemerintah kota Surabaya melalui web resmu sehingga memudahkan masyarakat dalam mengetahui program yang telah dilaksanakan oleh pemerintah, tidak terkecuali informasi tentang anggaran. Di samping itu, peneliti melakukan penelitian pada Satuan Kerja yang terkait. Peran SKPD dalam hal transparansi anggaran dan akuntabilitas sebagai pemberi informasi kemajuan dan pelaporan anggaran yang telah direncanakan dan diimplementasikan oleh pemerintah. Oleh karena itu penelitian dilaksanakanpada Badan Pengelolaan Keuangan dan Aset Daerah (BPKAD). 
Instansi yang lainnya yang diteliti adalah Dewan Perwakilan Rakyat Daerah Kabupaten Surabaya. DPRD Kota Surabaya memiliki andil dalam pembuatan anggaran, karena DPRD (Badan Anggaran) akan menyetujui anggaran yang telah dibuat oleh dinas (TAPD). Anggaran akan disesuaikan oleh program dan kegiatan yang diadakan oleh seluruh SKPD, sehingga akan diseimbangkan sesuai porsi dan program yang akan dilaksanakan. Penentuan informan dalam penelitian ini ditujukan kepada KPA kuasa pengguna anggaran tiap SKPD. Informan yang dipilih dianggap paling mengetahui dan memahami tentang permasalahan dalam penelitian ini. Teknik Pengumpulan Data dalam penelitian ini melalui tiga tahapan yaitu observasi, wawancara dan pencarian data tertulis yang mendukung. Data yang dimaksudkan yaitu data dalam bentuk dokumen, file, buku dan dokumen lain yang relevan dengan penelitian. Setelah data diperoleh, maka dilakukan analisis data. Analisis data dilakukan dengan metode analisis kualitatif yang mengacu pada siklus penelitian interaktif. Data yang terkumpul dikategorikan dalam bentuk yang mudah dibaca, dipahami dan diinterpretasikan, kemudian data diuraikan dalam bentuk uraian kualitatif dan dianalisis secara kualitatif yang terdiri dari reduksi data, penyajian data dan penarikan kesimpulan

\section{Hasil dan Pembahasan}

\section{Penerapan Sistem E-Budgeting pada Pemerintah Kota Surabaya}

Berdasarkan proses pelaksanaan nya penerapan sistem E-Budgeting, Kota Surabaya sudah berhasil menjalankan upayanya dalam melaksanakan prosedur operasional standar yang telah ditetapkan oleh Kepala Daerah dan Sekda bersama Tim Anggaran. Kota Surabaya sudah mendapatkan predikat baik dalam penerapan sistem E-Budgeting dan sekarang telah menjadi kota percontohan untuk penerapan sistem E-Budgeting di Indonesia.

Peran anggaran yang begitu besar dalam pelaksanaan kebijakan dan program pemerintahan, akan sangat beresiko jika dalam pelaksanaannya terjadi penyimpangan anggaran (korupsi). Selain itu pelaksanaan penganggaran di kota Surabaya juga dianggap sudah terbuka baik proses perencanaan program sampai dengan penganggaran di pemerintahan kota Surabaya. Dengan adanya kontrol dari masyarakat, diharapkan mampu memberikan aksesibilitas dan keterbukaan informasi dalam proses penganggaran. Sehingga terciptalah peran masayarakat untuk turut ikut serta dalam penyusunan program kegiatan pemerintah kota Surabaya. 


\section{Sistem e-budgeting terhadap Transparansi}

Proses penganggaran yang dilakukan pada pemerintahan kabupaten Blitar masih dilakukan secara manual. Namun, sebagai upaya pertanggungjawaban dan akuntabilitas anggaran, pemerintahan kabupaten Blitar melakukan publikasi terkait dokumen mulai perencanaan program sampai penganggaran, RAPBD sampai dengan APBD pada pemeritahan kota Surabaya. Memang dalam proses penganggaran masyarakat tidak ikut terlibat secara langsung, namun masyarakat dapat mengawasi jalannya proses penganggaran yang dilaksanakan oleh pemerintahan kota Surabaya. Dengan adanya website-website dari Bappeda, PPID, DPRD, BPKAD atau bahkan website transparansi anggaran masyarakat akan mudah mencari dokumen tentang perencanaan dan penganggaran, bagaimana prosesnya sejauh mana kegiatan nya berjalan. Salah satu indikator mengukur transparansi pelayanan publik adalah kemudahan masyarakat untuk memperoleh informasi mengenai berbagai aspek penyelenggaraan pelayanan publik. Hal ini diharapkan masyarakat juga dapat meningkatkan sistem kontrol dan pengawasan terhadap pemerintah dalam penganggaran di pemerintahan kota Surabaya.

\section{Sistem e-budgeting terhadap Akuntabilitas}

Hal tersebut yang melatarbelakangi adanya akuntabilitas sistem anggaran melalui sistem elektronik di pemerintahan kota Surabaya. Penganggaran yang sudah menggunakan sistem dapat meningkatkan tingkat partisipasi masyarakat. Selain itu, masyarakat juga dapat mengetahui proses dan informasi terkait tentang proses dan hasil dari penganggaran. Hal tersebut akan menimbulkan tingkat kepercayaan masyarakat tinggi kepada pemerintahan terkait tentang anggaran. Namun yang terlihat, posisi masyarakat masih tersisihkan diantara aktor-aktor lainnya, serta kurang proses pertanggungjawaban pemerintah kepada masyarakat. Untuk meminimalisir masalah kepercayaan masyarakat terhadap pemerintah dan adanya kontrol pengawasan kepada pemerintah tentang penganggaran maka pemerintahan kota Surabaya melakukan bentuk pertanggungjawaban dan keterbukaan informasi melalui sistem elektronik. Berkaitan dengan adanya keterbukaan informasi tentang penganggaran maka pemerintahan Kota Surabaya melaksanaakan koordinasi dan kerjasama antar SKPD dalam mewujudkan akuntabilitas dan transparansi anggaran. Satuan Kerja Perangkat Daerah yang terkait antara lain adalah : Bagian Administrasi Pembangunan, Badan Perencanaan Kota Surabaya, Badan Pengelolaan Keuangan dan Pajak Daerah kota Surabaya dan Dinas Komunikasi dan Informasi selaku Pejabat Pengelola Informasi dan Dokumentasi kota Surabaya. 


\section{Simpulan}

Kesiapan Pemerintah Kota Surabaya atas penerapan sistem E-Budgeting dilandasi Peraturan Menteri Dalam Negeri Nomor 21 Tahun 2011 tentang Pedoman Pengelolaan Keuangan Daerah. Sebagai bagian dari dasar penerapan sistem E-Budgeting sebagai berikut :

1. Penerapan sistem E-Budgeting Kota Surabaya sudah dapat diterapkan oleh setiap SKPD dan kelurahan, kecamatan dan dinas. Dimulai dari proses perencanaan, pelaksanaan dan evaluasi. Peran masyarakat dalam kebijakan penerapan sistem elektronik budgeting yaitu partisipasi dalam perencanaan awal membuat anggaran perlu adanya musyawarah antara pemerintah kota Surabaya dan RT/RW serta organisasi masyarakat. Membahas tentang program kerja Pemerintah kota Surabaya dengan menggunakan sistem e-musrenbang. Bertujuan untuk memudahkan Tim Anggaran berkomunikasi dalam membangun program kegiatan Pemerintah Kota Surabaya dalam proses membuat RKPD (Rencana Kerja Pemerintah Daerah) yang nantinya akan disampaikan kepada Walikota Surabaya untuk pembentukan APBD Kota Surabaya.

2. Pelaksanaan sistem E-Budgeting sudah dikatakan berjalan dengan baik sesuai prosedur yang sudah ditetapkan oleh Pemerintah Kota Surabaya. Tidak ada perbedaan dalam menerapkan sistem E-Budgeting tiap SKPD kota Surabaya. Jika ada permasalahan nanti nya tim Anggaran akan melakukan pendampingan agar tiap KPA SKPD bisa menggunakan sistem E-Budgeting dan tidak ada kejadian pelanggaran dalam sistem E-Budgeting.

Tercapai nya penerapan sistem E-Budgeting di Kota Surabaya yang melatarbelakangi tingkat kesuksesan nya yaitu adanya Sumber Daya Manusia yang memadai dan dukungan perangkat hardware yang membantu proses kelancara sistem $E$ Budgeting.

\section{Saran}

Berdasarkan pembahasan dan kesimpulan di atas, maka penulis memberikan beberapa saran sebagai berikut :

a. Diberikannya penghargaan pada Kota Surabaya sebagai kota percontohan dalam penerapan sistem E-Budgeting. Sebaiknya kota maupun daerah lainnya bisa mengadopsi sistem elektronik budgeting kota Surabaya. 
b. Bagi peneliti selanjutnya dalam meneliti tentang sistem E-Budgeting perlu dilakukan penelitian mengnai sistem pengawasan nya terhadap perencanaan hingga pelaporan sistem E-Budgeting.

c. Bagi pemerintah perlu memperhatikan kendala kendala yang mempengaruhi sistem E-Budgeting sehingga mendorong tiap SKPD dalam meningkatkan kualitas kinerja instansi lebih baik. 


\section{Daftar Pustaka}

Sutedi, Adrian. 2009. Implikasi Hukum Atas Sumber Pembiayaan Daerah dalam Kerangka Otonomi Daerah. Jakarta: S. Grafika, Ed.

Mustopadidjaya, AR. 2002. Manajemen Proses Kebijakan Publik, Formulasi, Implementasi dan Evaluasi Kinerja.

Arikunto, S. 2010. Penelitian Suatu pendekatan praktik. In Jakarta: PT Rineka Cipta.

Tjokroamidjojo, Bintoro. 2001. Reformasi Administrasi Publik. Jakarta.

Elizabeth Pinnington, J. L. \& D. S. 2009. Participatory Budgeting In North America: The Case Of Guelph. Canada, 21(3), 454-483.

Endrayani, K. S., Adiputra, I. M. P., \& Darmawan, N. A. S. 2014. Pengaruh Penerapan Anggaran Berbasis Kinerja Terhadap Akuntabilitas Kinerja Instansi Pemerintah (Studi Kasus pada Dinas Kehutanan UPT KPH Bali Tengah Kota Singaraja. EJournal S1 Akuntansi Universitas Pendidikan Ganesha, 2(1), 1-11.

Gallego-Álvarez, I., Rodríguez-Domínguez, L., \& García-Sánchez, I. M. 2010. Government Information Quarterly. Government Information Quarterly, 27(4), 423-430.

Halim \& Kusufi. 2012. Akuntansi Sektor Publik: teori, konsep dan aplikasi. Jakarta: Salemba Empat.

Mardiasmo. 2002. Akuntansi Sektor Publik. Penerbit Andi. Yogyakarta.

Moleong, L. J. 2013. Metode Penelitian Kualitatif. Bandung: Remaja Roskadaya, 54-66.

Mukhtar. 2013. Metode Praktis Penelitian Deskriptif Kualitatif. Gaung Persada Group. Jakarta: Referensi GP Press Group, 1st ed, 32-42.

Musmade, M. 2015. Participatory Budgeting - Concept and practice, 86-93.

Adrianto, Nico. 2007. Good e-government: Transparansi dan Akuntabilitas Publik melalui EGovernment. Malang.

P. Loina Lalolo Krina. 2003. Indikator dan Alat Ukur Prinsip Akuntabiitas, Transparansi dan Partisipasi. Jakarta.

Qadriyanti, N. L. 2013. Pengaruh Partisipasi Penyusunan Anggaran Dan Akuntansi. ILMU \& RISET AKUNTANSI, 2(11).

Rasul Syahrudin. 2003. Pengintegrasian Sistem Akuntabilitas Kinerja dan Anggaran dalam Perspektif UU NO. 17/2003 Tentang Keuangan Negara.

Rinaldi, R. R. 2016. Pengaruh Penerapan Good Governance, Audit Kinerja dan Standar Akuntansi Pemerintah Terhadap Akuntabilitas Keuangan Daerah. Universitas Muhamadiyah Surakarta, 1-12.

Sugiyono. 2010. Metode Penelitian Kuantitatif, Kualitatif Dan R\&D 11thed. In Bandung:Alfabeta.

Sistem E-Budgeting. 2017. Alur Penyusunan Anggaran Pemerintah Kota Surabaya (https://ebudgeting.surabaya.go.id/new_portal/ diakses tanggal 13 Juni 2017)

Tahir, A. 2011. Kebijakan Publik dan Transparansi Penyelenggaraan Pemerintahan Daerah. Jakarta. 